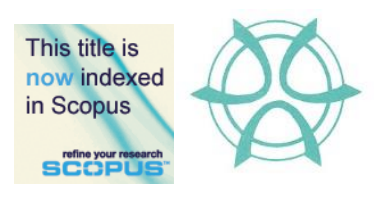

PLANNING MALAYSIA:

Journal of the Malaysian Institute of Planners

VOLUME 15 ISSUE 1 (2017), Page 271 - 278

\title{
ROLES OF COMMUNITY TOWARDS URBAN FARMING ACTIVITIES
}

\author{
Norul Hafizah binti Yusoff' ${ }^{1}$, Mohd Ramzi Mohd Hussain², \& Izawati Tukiman³ \\ ${ }^{1,2,3}$ Kulliyyah of Architecture and Environmental Design \\ INTERNATIONAL ISLAMIC UNIVERSITY MALAYSIA
}

\begin{abstract}
The aim of this paper is to review and analyse the importance of the framework for urban farming activities to be implemented within cities environment. This paper also describes the role of the community to achieve the environmental, economic and social sustainability for the enhancement of the urban environment and healthy lifestyles through community participation in food supplies, nutrition, and spaces utilization. The paper evaluates the benefits and potential of urban farming activities within limited urban spaces and how it improves the quality of life. It also reviews on how urban farming is beneficial to the society due to food shortage crisis which is inadequate for the whole population. It is necessary to apply and practice in our daily lives for the consumption of food security, human safety, and health. Therefore, the role of community is very crucial in the implementation of urban farming activities within urbanized areas as the demand for green development increases. Based on this theoretical framework, it is hoped that the paper will be a useful addition to the body of knowledge in promoting a stronger community interdependence to create the sustainable urban environment.
\end{abstract}

Keyword: Urban farming, role of community, importance, sustainable.

Date Received: $30^{\text {th }}$ April 2016

Date of Acceptance: $30^{\text {th }}$ October 2016 
Norul Hafizah Yusoff, Mohd Ramzi Mohd Hussain, \& Izawati Tukiman

Roles of Community Towards Urban Farming Activities

\section{INTRODUCTION}

Aggressive development challenges the human mind to trigger innovative ideas to create sustainable development in fast growing cities. Certainly, urban farming is widely practiced by the society in rapid urbanization areas, cities and town spaces (Bellows, Brown \& Smit, 2003). Suryandari (2012) reported that urban farming activities had been introduced to reduce and overcome the environmental, economic and social problems other than to fulfil people needs and demands.

With regards to the implementation of urban farming, theory on The Garden City Movement initiated by Sir Ebenezer Howard during the year of 1898 has proved that urban farming concept is not a new idea. In retrospect, The Garden City Movement method emphasized on the combination of town and country to offer an alternative to working class in crowded and unhealthy cities (ACT Planning and Land Authority, 2003). It was intended to create cities with economically independent and countryside's preservation. Indeed, the connection between foods and the city had already evolved since ancient times.

Although urban farming is not new worldwide, it is yet to become popular in Malaysia due to lack of awareness and participation from community (Islam \& Siwar, 2012; Kaur \& Hitam, 2010). Thus, the objectives of this paper are to identify the role of community in the urban farming activities towards sustainable urban environment, and to explore the benefits and potential of urban farming activities and how it improves the quality of life.

\section{URBAN FARMING}

Thoreau (2010) defines urban farming as food or livestock growth or processes that are undertaken within the urban area or around the urban centres with the purpose to generate income. Likewise, Watson (2015) also discovered that urban farming is about raising foods including plants and animals in the city ground either at allotment land or non-occupied space. In the context of Malaysia, urban farming is often recognized as "pertanian bandar" or "kebun bandar". Izham Alias, whom the founder of Kebun Bandar: Jom Tanam Sendiri stated that urban farming is an activity that helps to encourage communities to plant crops while saving expenses on foods, which at the same time significantly related to the ecology, health, sustainability and food security (Md Sani, 2016; Mat \& Abdul Majid, 2015). Urban farming activity is also beneficial to the society especially urban communities and helps to lessen the problem of food shortage and limited spaces for agriculture (Giedych, 2015; Smith, 2005).

\section{Types of Urban Farming}

The application of urban farming varies from every corner of urban settings and its ecosystem. Considering the necessity of urban farming, several studies reported that urban farming has already been implemented on grounds, and on 
PLANNING MALAYSIA

Journal of the Malaysia Institute of Planners (2017)

balcony and rooftop of buildings, as well as on vertical walls, in various cities in different climatic environment, including high-density cities like in the United State of America, Japan, Singapore and many others (Shanshan \& Ge, 2013; Hui, 2011).

There are three types of urban farming identified, which are community farming, rooftop farming and vertical farming. Each farm shares similar practices and purposes with specific characteristics due to space organizations and boundaries.

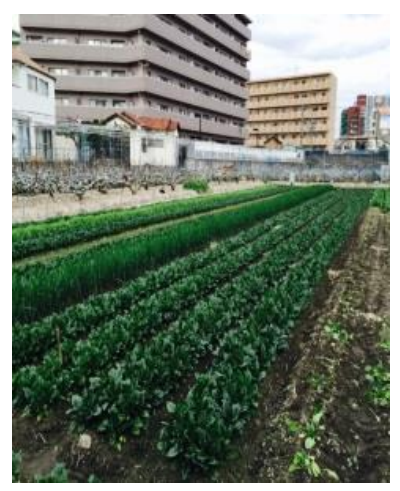

Community Farming in Japan

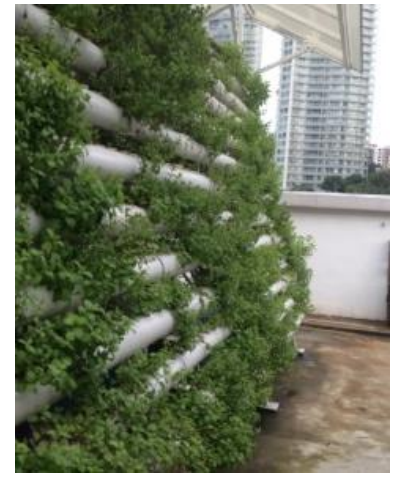

Rooftop Farming in Singapore

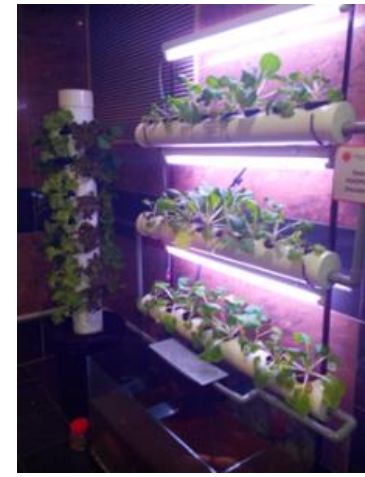

Vertical Farming in Malaysia

Figure 1 Types of Urban Farming

\section{Benefits and Potential of Urban Farming}

The benefits and potential of urban farming towards the community can be categorised into four, which are environmental stewardship (Lydecker \& Drechsel, 2010; HB Lanarc-Golder, 2013), economic reliance (Giedych, 2015; Lyson, Gillespie \& Hilchey, 1995), social improvement (Scott, 2015; Sharp, Imerman \& Peters, 2002; Feenstra, 1997) as well as health and nutrition (Kumar, 2015). Cabannes (2006) reported that urban farming is also an investment strategy in developed countries to bring urban people back to nature, opening eyes and minds to the global issues, and to educate children from the natural cycle of life through landscape environment. Besides, urban farming is also seen as an effective measure to increase green spaces, vegetation fields and gardens for recreational purposes and urban revitalization (Wackernagel \& Rees, 1996). It is a strategy in the form of "shifting cultivation" by creating new open spaces from unutilized land (Veenhuizen, 2006). By managing the land surfaces, it will improve and conserve the ecological integrity and environment of the city. 
Norul Hafizah Yusoff, Mohd Ramzi Mohd Hussain, \& Izawati Tukiman

Roles of Community Towards Urban Farming Activities

Table 1 Four Benefits and Potential of Urban Farming

\begin{tabular}{|c|c|}
\hline $\begin{array}{c}\text { Environmental Stewardship } \\
\text { - } \text { Urban revitalization } \\
\text { - } \text { Ecosystem enhancement } \\
\text { - } \text { Climate changes } \\
\text { - } \text { Sound reduction } \\
\text { - Noise absorption } \\
\text { - } \text { Minimize transport footprints } \\
\text { - Enrich visual quality }\end{array}$ & $\begin{array}{l}\text { Economic Reliance } \\
\text { - } \text { Free-cash nutrient } \\
\text { - } \text { Lowering expenditure } \\
\text { - } \text { Green innovation } \\
\text { - Employment creation } \\
\text { - } \text { Introduce local food production } \\
\text { Positive economic description }\end{array}$ \\
\hline $\begin{array}{l}\text { Social Improvement } \\
\text { - Community empowerment } \\
\text { - } \text { Youth development and training } \\
\text { - } \text { Cultural integration and } \\
\text { preservation } \\
\text { - Positive community interaction } \\
\text { and social well-being }\end{array}$ & $\begin{array}{l}\text { Health and Nutrition } \\
\text { - Food access and security } \\
\text { - Organic fruits and vegetables } \\
\text { - Nutrient retention } \\
\text { - Therapeutic treatment } \\
\text { - Amenity recreational and garden } \\
\text { - } \text { spaces } \\
\text { - } \text { Physical activities and exercises } \\
\end{array}$ \\
\hline
\end{tabular}

\section{THE ROLES OF COMMUNITY IN URBAN FARMING ACTIVITIES}

Community perception and participation in urban farming is highly related to the level of awareness of the benefits of the activity. To be successful, it is important that community involvement is kept continuous in the implementation of urban farming.

\section{Community Perception}

Russell (2008) discovered perception as the way of people grouping particular matters into things or perspectives which derived from sensations or images. It is the way people classify things through the ability of sensory and reaction of their personal judgment. People can acknowledge something through physical senses by seeing, hearing, tasting and feeling during certain situations. They get to understand, interpret and become aware on something from their point of views and giving the opinions based on the limited knowledge a person has.

\section{Community Participation}

World Health Organization (2002) define community participation as to actively involved or taken part in the community development issues and strategies through the physical actions taken by the neighbourhood members in the particular community area. Likewise, Burns et al. (2004) note that community participation is associated with the individuals' or groups' opportunities of sharing some involvement and engagements in the decision-making process. They get to express themselves by showing their concerns through the significant 
PLANNING MALAYSIA

Journal of the Malaysia Institute of Planners (2017)

physical powers, efforts and influences which they had clearly understood and realize about the importance of something that may help in changing and enhancing their quality of lifestyles.

A positive correlation was found by Banning (2015), indicating that the practices of urban farming activity are linked with the commitment and the awareness of urban communities towards preserving and protecting the natural resources for future growth through establishing environmentally-friendly educational community programs held in the neighbourhood green spaces. Access to food supplies and knowledge of health among the communities will also provide positive outcomes to the number of participations of the urban community in urban farming (Trutko, 2014).

\section{Sustainable Urban Environment}

Considerable evidences support the notion that the public play important roles in in creating sustainable urban environment through the practice of urban farming. Although many researchers have mentioned about the benefits of urban farming activities in the urban context, very few studies regarding urban farming have been conducted in Malaysia (Islam \& Siwar, 2012; Kaur \& Hitam., 2010). This is because urban farming in Malaysia is currently lacking public support, especially in terms of public participation.

Table 2 presents the relationship between community participation with the urban farming activities towards sustainable urban environment. According to recent researches as in Table 2, urban farming activities can provide opportunities in fostering community building and support environmental education.

Table 2 Relationship between Community Participation in Urban Farming Activities and Sustainability

\begin{tabular}{|c|c|c|c|}
\hline Sources & $\begin{array}{c}\text { Urban Farming } \\
\text { Activities }\end{array}$ & Community Participation & $\begin{array}{c}\text { Sustainable Urban } \\
\text { Development }\end{array}$ \\
\hline $\begin{array}{l}\text { Evan, Valsecchi } \\
\text { \& Polastri } \\
(2012)\end{array}$ & $\begin{array}{l}\text { Matter of awareness } \\
\text { about progressive } \\
\text { detachment in the } \\
\text { reality of food } \\
\text { production knowledge. }\end{array}$ & $\begin{array}{l}\text { Hesitation due to the } \\
\text { different attitude and } \\
\text { perceptions (farming is } \\
\text { rural and traditional } \\
\text { senses). }\end{array}$ & $\begin{array}{l}\text { It is necessary to maintain } \\
\text { a growing and living } \\
\text { spaces in the changing } \\
\text { environment. }\end{array}$ \\
\hline $\begin{array}{l}\text { Peemoeller } \\
(2011)\end{array}$ & $\begin{array}{l}\text { For future, people need } \\
\text { to understand the } \\
\text { relevance of food in } \\
\text { their lives. }\end{array}$ & $\begin{array}{l}\text { Engage and educate the } \\
\text { public about healthy and } \\
\text { sustainable food systems. }\end{array}$ & $\begin{array}{l}\text { Community leadership is } \\
\text { essential, recognize the } \\
\text { strength of diversity. }\end{array}$ \\
\hline $\begin{array}{l}\text { Funders' } \\
\text { Network (2011) }\end{array}$ & \begin{tabular}{|lr} 
Physical, technical, \\
educational r and \\
programmatic support \\
is important to urban \\
agriculture success and \\
longevity
\end{tabular} & $\begin{array}{lr}\text { Absences of } & \text { community } \\
\text { engagement } & \text { and } \\
\text { opportunities (lack of } \\
\text { supportive public policies } \\
\text { and community visioning). }\end{array}$ & - \\
\hline
\end{tabular}


Norul Hafizah Yusoff, Mohd Ramzi Mohd Hussain, \& Izawati Tukiman

Roles of Community Towards Urban Farming Activities

\begin{tabular}{|c|c|c|c|}
\hline $\begin{array}{l}\text { Kaur \& Hitam } \\
(2010)\end{array}$ & - & $\begin{array}{l}\text { Lack of community } \\
\text { participation in sustainable } \\
\text { program. }\end{array}$ & $\begin{array}{l}\text { Local Agenda } 21 \text { - fewer } \\
\text { authorities efforts "words } \\
\text { are, action not". }\end{array}$ \\
\hline $\begin{array}{l}\text { Rujiroj } \\
\text { Anambutr } \\
(2010)\end{array}$ & - & $\begin{array}{llr}\text { Community } & \text { need } & \text { for } \\
\text { motivation and application } \\
\text { experiences } & \text { for } & \text { better } \\
\text { understanding } & & \text { and } \\
\text { awareness to } & \text { gain } & \text { good } \\
\text { results. } & & \\
\end{array}$ & $\begin{array}{l}\text { Policy } \rightarrow \text { apply } \rightarrow \\
\text { enforcement } \\
-\quad \text { time, efforts and } \\
\text { cooperation are needed. }\end{array}$ \\
\hline $\begin{array}{l}\text { Victor Rubin } \\
(2008)\end{array}$ & - & $\mid$\begin{tabular}{lrr} 
Increase & \multicolumn{2}{c}{ environmental } \\
justice campaign from \\
development projects $\&$ \\
healthier activities
\end{tabular} & $\begin{array}{l}\text { Contribution of greening- } \\
\text { need diverse methods and } \\
\text { supports, connection for } \\
\text { green movement. }\end{array}$ \\
\hline
\end{tabular}

\section{CONCLUSION}

Scholars agreed that there is a widespread realization of efforts and determination aimed at the restoration and preservation of natural ecosystem. This has, to an extent, promote the rapid emergence of urban farming especially in relation to meeting demand for local food and resilient community (HB Lanarc-Golder, 2013). However, the success of urban farming is dependent on many factors, most importantly the perception and participation of the local community. Active community participation indicates the power and control of the community in the decision-making as according to their demands for environmental justice and community interdependence for better well-being (Kumar, 2015; Burns et al., 2004; Rubin, 2008). Several scholars indicated that community involvement in the urban farming activities can help strengthen the ties between communities (Sharp, Imerman \& Peters, 2002; Nemore, 2015). Farming itself can build a strong and vibrant brotherhood, create a sense of partnerships, and enhance community cohesion as well as diverse cultures among the growers and farmers.

Urban farming has existed in many cities throughout the world. It provides a valuable complimentary farming activity to the urban residents. It is time for urban farming to also enjoy popularity in Malaysia. Further researches are required to look at other criteria of urban farming like sustainability strategy and investment returns so that the public as well as the authorities in Malaysia can be convinced to implement urban farming in their cities. 


\section{REFERENCES}

ACT Planning and Land Authority (2008). Garden City values and principles - design considerations for residential development in inner North and South Canberra.

Anambutr, R. (2010). Moving toward eco-friendly city: Perspective on Thailand. In L. L. Fook, C. Gang (Eds.), Towards a liveable and sustainable urban environment: eco-cities in East Asia, p. 107-128. Singapore: World Scientific.

Banning, J. (2011). Food (and farms) for thought: campus farming and environmental sustainability. Retrieved October 21, 2015 from http://blogs.worldwatch.org/nourishingtheplanet/food-and-farms-for-thoughtcampus-farming-and-environmental-sustainability.

Bellows, A. C., Brown, K., \& Smit, J. (2003). Health Benefits of Urban Agriculture. Community Food Security Coalition, 19, 702-703.

Burns, D., Heywood, F., Taylor, M., Wilde, P., \& Wilson, M. (2004). Making community participation meaningful: a handbook for development and assessment. Bristol The Policy Press.

Cabannes, Y. (2006). Financing and investment for urban agriculture. In R. V. Veenhuizen (Ed.), Cities farming for the future, p.87-124. Silang, Philippines: International Institute of Rural Reconstruction.

Evans, S., Valsecchi, F., \& Pollastri, S. (2012). Design for distributed and networked urban farming in Shanghai. Cumulus 2012. Helsinki, Finland.

Feenstra, G. W. (1997). Local food systems and sustainable communities. American Journal of Alternative Agriculture, 12(1), 28-36.

Funders' Network (2011). Investing in healthy, sustainable places through urban agriculture (Translation paper 5).

Giedych, R. (2013). Urban agriculture: structure, functions, future challenges. Global Landscapes Forum. Warsaw, Poland.

HB Lanarc-Golder (2013). The urban farming guidebook: planning for the business of growing food in $B C$ 's towns and cities. Vancouver.

Hui, S. C. M. (2011). Green roof urban farming for buildings in high-density urban cities. The 2011 Hainan China World Green Roof Conference. Hainan, China.

Islam, R., \& Siwar, C. (2012). The analysis of urban agriculture development in Malaysia. Advances in Environmental Biology, 6(3), 1068-1078.

Kaur, H., \& Hitam, M. (2010). Sustainable living: an overview from the Malaysian perspective. In L. L. Fook, C. Gang (Eds.), Towards a liveable and sustainable urban environment: eco-cities in East Asia, p. 159-178. Singapore: World Scientific.

Kumar, R. (2012). Five reasons why urban farming is the most important movement of our time. Retrieved December 22, 2015 from: http://magazine.good.is/articles/five-reasons-why-urban-farming-is-the-mostimportant-movement-of-our-time.

Lydecker, M., \& Drechsel, P. (2010). Urban agriculture and sanitation services in Accra, Ghana: the overlooked contribution. International Journal of Agricultural Sustainability, 8(1), 94-103.

Lyson, T., Gillespie, G., \& Hilchey, D. (1995). Farmers' markets and the local community: bridging the formal and informal economy. American Journal of Alternative Agriculture, 10(3), 108-113. 
Norul Hafizah Yusoff, Mohd Ramzi Mohd Hussain, \& Izawati Tukiman

Roles of Community Towards Urban Farming Activities

Mat, R., \& Abdul Majid, A. (2015). Kepentingan pertanian bandar dan cabaran yang dihadapi oleh petani bandar di Malaysia. International Journal of Environment, Society \& Space, 3(1), 44-56.

Md Sani, M. S. (2016). Bantu warga bandar bertani. HM Online. Retrieved March 16, 2016 from http://www.hmetro.com.my/node/24925?m=1

Nemore, C. (1998). Rooted in community: community gardens in New York City. City Farmer. $\quad$ Retrieved November $12, \quad 2015$ from http://www.cityfarmer.org/NYcomgardens.html.

Peemoeller, L. (2011). Sustainable food system. In S. Coyle (Ed.) Sustainable and resilient communities: A comprehensive action plan for towns, cities, and regions, p. 269-283. Hoboken, New Jersey: John Wiley \& Sons.

Rubin, V. (2008). The roots of the urban greening movement. In E. Birch, S. Wachter (Eds.), Growing Greener Cities, p. 187-. Philadelphia: University of Pennsylvania Press.

Russell, B. (2008). Lecture VII: definition of perception, the analysis of mind. LLC: NuVision Publications.

Scott, E. (2012). Why gardening beats reading for stress relief. Retrieved October 17, 2015 from http://stress.about.com/od/generaltechniques/a/gardening.htm.

Shanshan, D., \& Ge, C. (2013). Multiple functions of urban farming. Retrieved October 17, 2015 from http://www.pcd.org.hk/en/newsletter/multiple-functions-urbanfarming.

Sharp, J., Imerman, E., \& Peters, G. (2002). Community Supported Agriculture (CSA): building community among farmers and non-farmers. Journal of Extension, 2002. Retrieved October 14, 2015 from http://www.joe.org/joe/2002june/a3.html.

Smith, D. L. (2005). Urban and peri-urban agriculture as a public policy issue. Workshop on Policy Prospects for Urban and Peri-Urban Agriculture in Kenya. Nairobi, Kenya.

Suryandari, R. Y. (2012). Urban farming and its impact on local communities and urban environment: A case study of West Jakarta and Tangerang, Indonesia. Malaysian Journal Society and Space, 8(3), 12-22.

Thoreau, C. (2010). Defining urban farming. Vancouver Urban Micro. Retrieved November 19, 2015 from http://cmthoreau.wordpress.com/2010/10/15/definingurban-farming/.

Trutko, A. (2014). Perceived outcomes of a community-based urban agriculture and nutrition education program: a case study of Common Good City Farm's Green Tomorrows program in Washington, D.C. IGARSS 2014. Quebec, Canada.

Veenhuizen, R. V. (Ed.) (2006). Cities farming for the future. Silang, Philippines: International Institute of Rural Reconstruction.

Wackernagel, M., \& Rees, W. (1996). Our ecological footprint: reducing human impact on the earth. Gabriola Island, BC: New Society Publishers.

Watson, M. (2014). What is an urban farm? About Food. Retrieved November 14, 2016 from http://localfoods.about.com/od/localfoodsglossary/g/What-Is-An-UrbanFarm.htm/

World Health Organization (2002). Community participation in local health and sustainable development: approaches and techniques. Copenhagen: WHO Regional Office for Europe. 